\title{
Immunological, hematological, biochemical, and histopathological studies on cows naturally infected with lumpy skin disease
}

\author{
Ahmed N. F. Neamat-Allah
}

Department of Clinical Pathology, Faculty of Veterinary Medicine, Zagazig University, 1 Alzeraa Street, Postal Code 44511, Zagazig City, Sharkia Province, Egypt.

Corresponding author: Ahmed N. F. Neamat-Allah, e-mails: drnemovete@yahoo.com, a_neamatallah@yahoo.com Received: 16-05-2015, Revised: 20-08-2015, Accepted: 28-08-2015, Published online: 23-09-2015

doi: 10.14202/vetworld.2015.1131-1136 How to cite this article: Neamat-Allah ANF (2015) Immunological, hematological, biochemical, and histopathological studies on cows naturally infected with lumpy skin disease, Veterinary World 8(9): 1131-1136.

\begin{abstract}
Aim: Lumpy skin disease (LSD) is an infectious viral disease of cattle caused by LSD virus (LSDV) of the family Poxviridae characterized by skin nodules covering all parts of the body. There are many aspects of LSD remaining unknown, thus immunological, hematological, and biochemical parameters were estimated.

Materials and Methods: During an outbreak of LSD in Sharkia governorate from Egypt, 211 cows aging (2-4 years) were examined clinically for the presence of LSD lesions during the period from July to November 2014. A total of 134 cows from those showed lesions suspected to be LSD.

Results: Recorded clinical signs were pyrexia with the development of skin nodules of varying sizes which ranged from a few to several hundred sometimes coalesced together. Enlargements of the peripheral lymph nodes. Intracytoplasmic inclusion bodies were noticed in the histopathological examination. Immunological studies revealed a significant decrease of lymphocyte transformation rate, phagocytic $\%$ and killing $\%$ which was marked within 2 weeks postinfection. LSD resulted in non-significant in hemogram in $1^{\text {st }}-2^{\text {nd }}$ day post-infection while a macrocytic hypochromic anemia within $10-14^{\text {th }}$ days post-infection. Leucopenia and lymphopenia were recorded $1^{\text {st }}-2^{\text {nd }}$ day post-infection while at $10-14^{\text {th }}$ showed granulocytic leucocytosis. Biochemical analysis revealed hypoproteinemia, hypoalbuminemia, and hyperglobulinemia especially gamma globulins. There were a significant increase in serum alanine aminotransferase, aspartate aminotransferase activities, creatinine level, blood urea nitrogen and creatine phosphokinase
\end{abstract}

Conclusion: LSDV infected cows in early stages revealed leucopenia. Immunosuppressive effect was pronounced later. In late stage revealed hemolytic anemia, leucocytosis and increase of serum CK, which could aid in diagnosis. Disturbance in liver and kidney function tests have been occurred.

Keywords: biochemistry, cows, hematology, histopathology, lumpy skin disease, virus.

\section{Introduction}

Lumpy skin disease (LSD) is an infectious viral disease of cattle caused by LSD virus (LSDV) of the family Poxviridae virus known as (Neethling virus) characterized by fever and sudden eruption of multiple skin nodules covering all parts of the body [1]. LSD was first seen as an epidemic in Zambia in 1929, and since then has spread and affected cattle throughout Africa, including the countries of South Africa, Egypt, and Sudan [2]. Severe cyclic outbreaks continue to occur in Egypt during 1989, 2006 and 2011 were recorded in several Egyptian governorates, and then incursion of LSD was reported for the first time in Iraq and Turkey in 2013, indicating that the disease has a potential risk for further spread to the European Union and Caucasus Region, as well as to Asia [3-5]. The disease listed by OIE [6] in "List A" due to its rapid spread and severe economic losses, such as decrease in milk production and weight gain, mastitis, infertility, and death $[7,8]$.

LSDV is primarily transmitted by biting insects. The virus have been isolated from mosquitoes of the

Copyright: The authors. This article is an open access article licensed under the terms of the Creative Commons Attributin License (http:// creative commons.org/licenses/by/2.0) which permits unrestricted use, distribution and reproduction in any medium, provided the work is properly cited. genera Aedes and Culex and Ixodid ticks during some outbreaks [9] while direct contact between animals is not likely to be a significant source of spread of LSDV [4].

Despite of LSD could be diagnosed using serological and molecular techniques [10,11], histopathological examination remain an important tool to exclude viral, bacterial, or fungal causes development of skin nodular lesions in clinical cases and characteristic cytopathic effects (ballooning degeneration of squamous epithelial cells and eosinophilic intracytoplasmic inclusion bodies) in cases of LSD are well documented $[12,13]$, but there are many aspects of LSD that remain unknown, so the immunological, hematological, and biochemical parameters of LSDV naturally infected cows were estimated in this study.

\section{Materials and Methods}

\section{Ethical approval}

Ethical approval from the Egyptian Veterinary Medicine Authority was obtained.

\section{Animal}

During an outbreak of LSD in Sharkia governorate in Egypt, 211 cows aging (2-4 years) were examined clinically for the presence of LSD lesions during the period from July to November 2014. A total of 
134 cows from those showed lesions suspected to be LSD. The animals were feverish, had multiple skin nodules and enlargement of superficial lymph nodes typical of LSD. Treatment was including washing by water, and dressing by povidone iodine and diclofenac sodium with oxytetracycline $20 \%$ long acting, as antipyretic administration and broad spectrum antibiotics. Another 10 healthy cows were used like normal control.

\section{Blood sampling}

Blood was collected by puncture of the jugular vein from cows into three samples. The first blood samples were taken in heparinized tubes for immunological studies. The second blood samples were taken into ethylenediaminetetraacetic (EDTA) tubes for hematological analysis. The third blood samples were taken in a sterile test tube for separation of serum that was used for biochemical measurements. Samples were collected at $\left(1^{\text {st }}-2^{\text {nd }}\right.$ days $)$ and $\left(10-14^{\text {th }}\right)$ days post appearance of skin nodules.

\section{Immunological studies}

A lymphocytic transformation assay using 3-(4,5-dimethylthiazol-2-71)-2, 5-diphenyl $2 \mathrm{H}$ tetrazolium bromide was used with $2348-71-2$ which is a methyl tetrazolium dye staining procedure [14]. Blood samples were collected in heparinized tubes and used to prepare leucocyte for bacterial phagocytic activity and killing power [15].

\section{Hematological examination}

Complete blood count was evaluated in an automatic cell counter (Hospitex Hemascreen 18, Italy).

\section{Biochemical examination}

Protein electrophoresis was quantitatively measured [16], while creatine phosphokinase (CK-MM) was measured in full automated biochemistry analyzer (Chemray 240. USSR). Serum activities of alanine and aspartate aminotransferase (ALT and AST) were determined [17], serum creatinine and blood urea nitrogen levels were estimated $[18,19]$.

\section{Histopathological studies}

Selected skin nodules from affected animals were surgically removed after local anesthesia then fixed in $10 \%$ buffered neutral formalin solution, dehydrated in gradual ethanol (70-100\%), cleared in xylene, and embedded in paraffin. Five micron thickness paraffin sections were prepared and then routinely stained with hematoxylin and eosin $(\mathrm{H}$ and $\mathrm{E})$ dyes. The sections were mounted with Canada balsam and covered with the cover slide to be ready for histopathological examination [20].

\section{Statistical analysis}

Data obtained from this investigation were statistically analyzed using the one-way analysis of variance using SPSS 16.0 for windows [21]. Means in the same row followed by different letters were significantly different, and the highest value was represented with the letter (a).

\section{Results and Discussion}

LSD is a pox viral disease of cattle with a major socio-economic impact [22-24]. The LSD was confirmed by the presence of characteristic pathognomonic [12], eosinophilic intracytoplasmic inclusion bodies in the prickle cell layer (Figure-1) by histopathological examination of surgically removed skin nodules. Recorded clinical signs in this study were in agreement with the previous studies [12,13,25] who mentioned that LSD infected animals showed, pyrexia $40-41{ }^{\circ} \mathrm{C}$ for large release and rapid clearance of pyrogens [25]. Skin nodules which ranged from a few to several hundred sometimes coalesced together. Later these nodules may be contained a clear serous or purulent exudates furthermore ulcers formation (Figures-2-4). Edema of the ventral abdominal wall and enlargement of superficial lymph nodes could be seen (Figures-5 and 6) [12]. Nasal discharge could be seen as a result of extent of infection to the upper respiratory tract (Figure-7) [7,12].

The innate immune response is the first line of defense of the immune system of the host and is

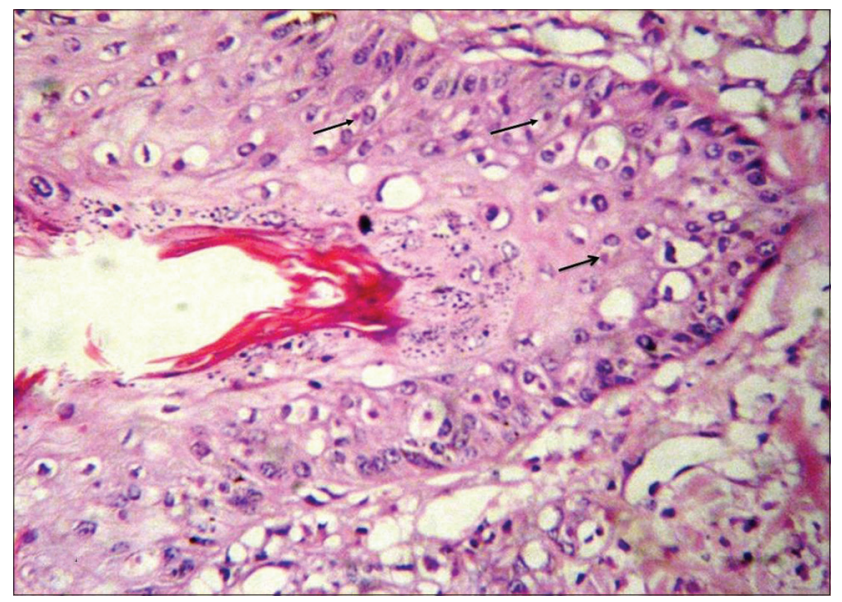

Figure-1: Lumpy skin disease, skin of cow showing ballooning and degeneration of prickle cell layer with scattered intracytoplasmic inclusion bodies (arrows), $\mathrm{H}$ and $\mathrm{E}, \times 1200$.

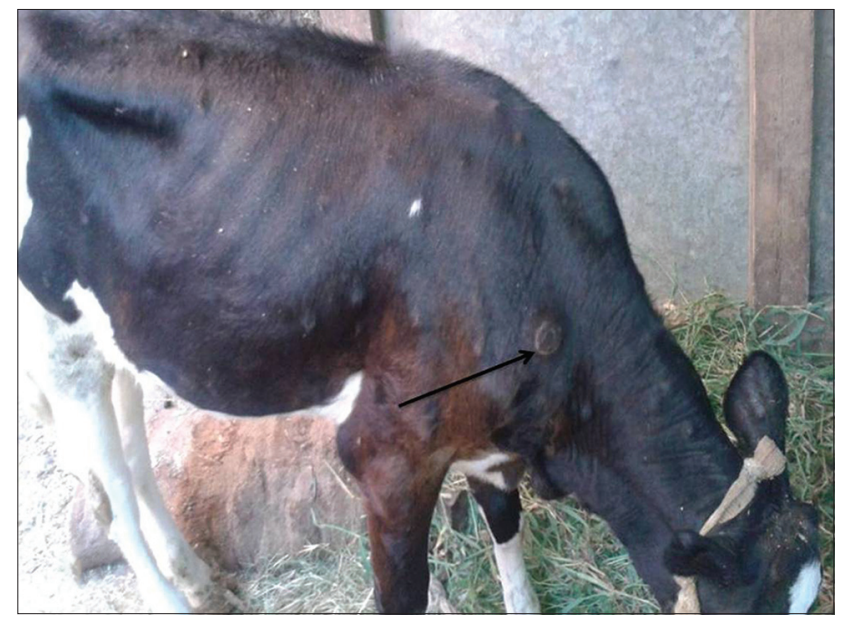

Figure-2: Lumpy skin disease in cow showing few skin nodules. 


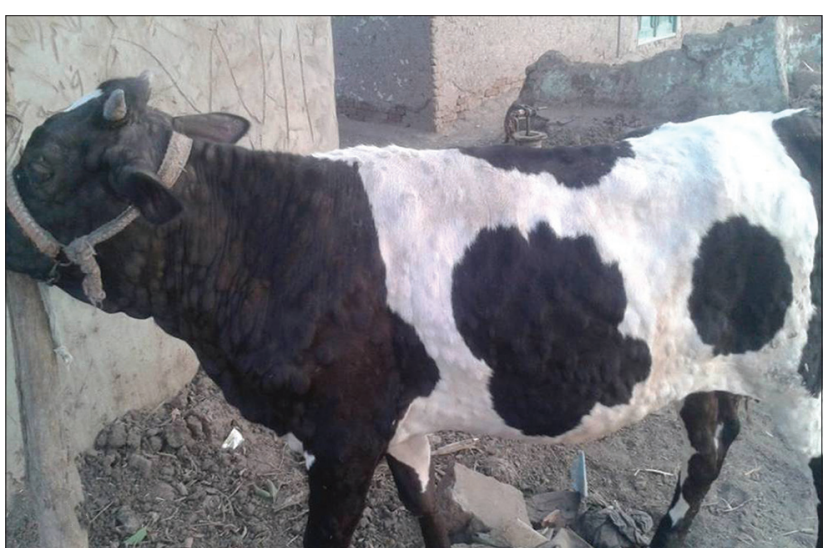

Figure-3: Lumpy skin disease in cow showing skin nodules cover all body parts.

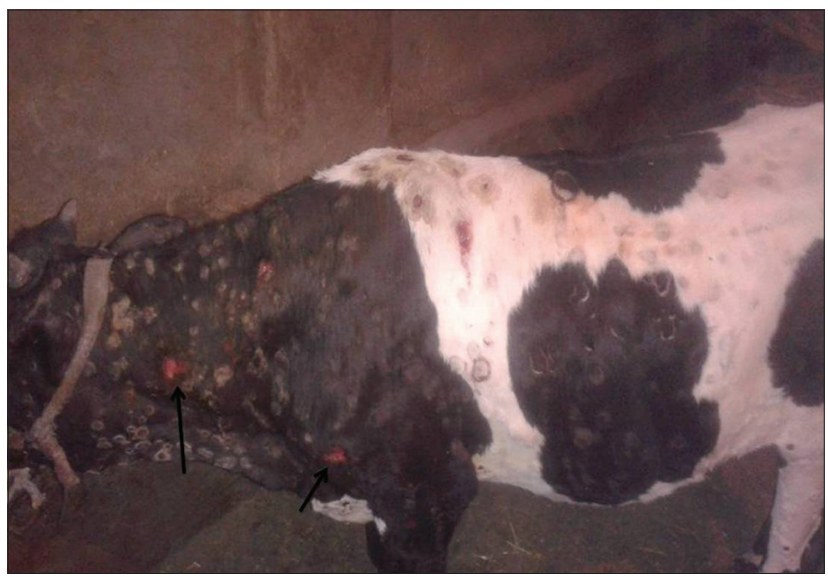

Figure-4: Lumpy skin disease in cow showing skin nodules leaving ulcer (14 days post-infection).

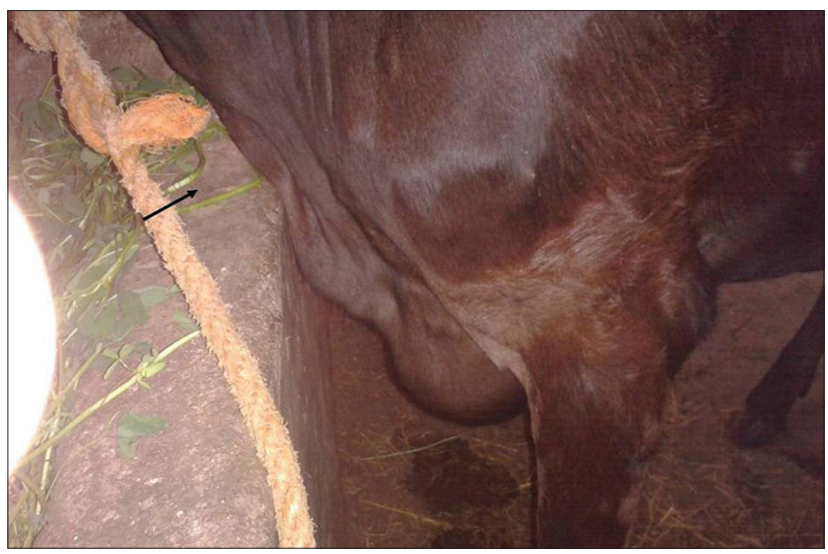

Figure-5: Lumpy skin disease in cow showing edema of ventral abdominal.

needed for stimulating the adaptive immune response. The cellular components of the innate immune system, namely macrophages and neutrophils are critical for controlling microbial infection. These immune cells destroy the pathogen by phagocytosis and production of reactive oxygen species [26]. In the presented study, immunological parameters revealed a significant decrease of lymphocyte transformation rate, phagocytic activity and killing percentage which was marked within 2 weeks post-infection (Table-1)

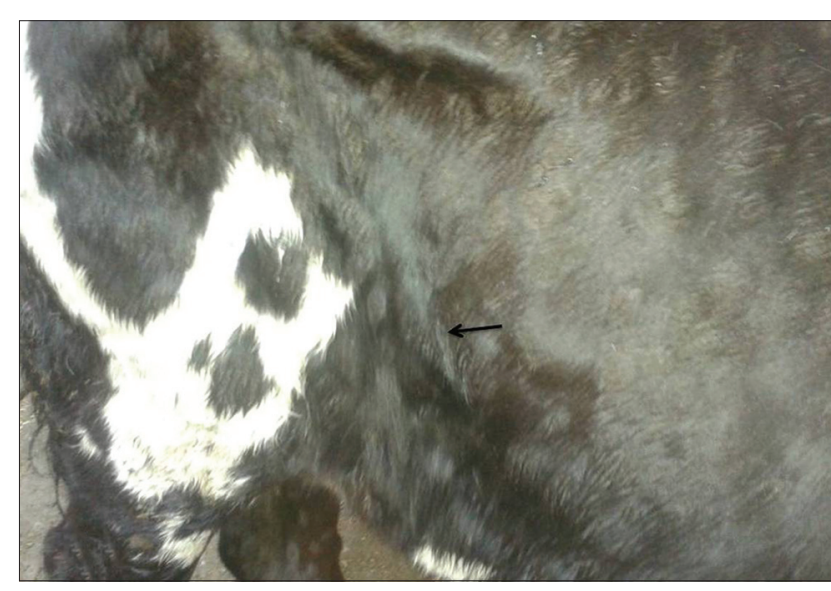

Figure-6: Lumpy skin disease in cow showing enlargement of precrural lymph node.

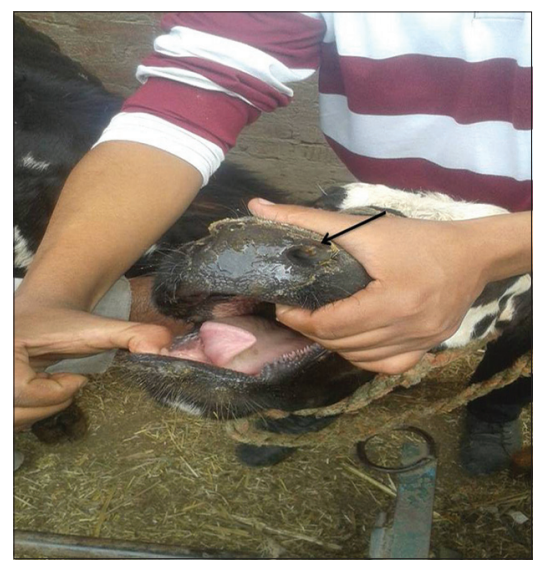

Figure-7: Lumpy skin disease in cow showing nodules and ulcer on upper respiratory.

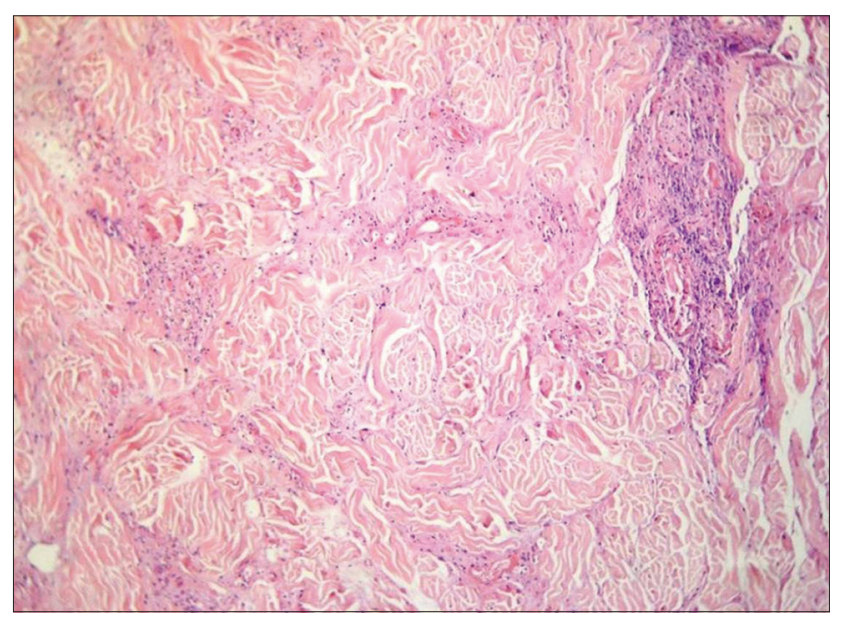

Figure-8: Lumpy skin disease, subcutaneous muscle of cow showing sever coagulative necrosis and calcification, $\mathrm{H}$ and $\mathrm{E}, \times 1200$.

that may be due to LSD followed by secondary bacterial invasion in addition to stress induced immunosuppression [3].

Regarding to the erythrogram results (Table-2) revealed non-significant change in hemogram within $1^{\text {st }}-2^{\text {nd }}$ day post-infection. At $10-14^{\text {th }}$ day LSD post-infection revealed a significant decrease in red blood cells, hemoglobin, packed cell volume, and mean 
corpuscular hemoglobin concentration with a significant increase in mean corpuscular volume when compared by healthy control. This result interpreted as a macrocytic hypochromic anemia which in agreement with [27] who reported that hemolytic anemia could be occurred with viral infection. On the other side leucogram results (Table-3) during $1^{\text {st }}-2^{\text {nd }}$ days post-infection revealed leucopenia and lymphopenia which may be due to viral infection [28]. These results agree with [25] who recorded that a release of large quantities of endogenous corticosteroid could account for a lymphopenia. While $10-14^{\text {th }}$ day post-infection revealed granulocytic leucocytosis which could be due to secondary acute bacterial infections, especially pyogenic bacterial infections $[28,29]$.
Regarding to results of biochemical analysis (Table-4) revealed a significant decrease in total protein and albumin, however; there was a significant increased in globulin, especially gamma globulins in LSD infected cows. These results might be attributed to decreased protein synthesis and higher catabolic rate, as well as damaged liver parenchyma [30]. While increased globulin, especially gamma globulins were mainly an immune response following infection [31]. The significant increase of CK in LSD infected cows clearer in late stage could be due to muscle damage involvement [32] that confirmed with histopathological examination which showing sever coagulative necrosis in subcutaneous muscle (Figure-8). So, LSD has economically

Table-1: Alteration in lymphocyte transformation rate, phagocytic $\%$ and killing $\%$ in cows naturally infected with LSD virus (mean values $\pm \mathrm{SE}$ ).

\begin{tabular}{|c|c|c|c|c|}
\hline \multicolumn{5}{|c|}{ Groups } \\
\hline \multirow[t]{3}{*}{ Parameters } & \multirow{3}{*}{$\begin{array}{c}\text { Healthy } \\
\text { control } \\
\text { cows }\end{array}$} & \multicolumn{3}{|c|}{ LSD infected cows } \\
\hline & & \multicolumn{2}{|c|}{ Post-infection } & \multirow[t]{2}{*}{ F test } \\
\hline & & $1^{\text {st-2 }} 2^{\text {nd }}$ day & $10-14^{\text {th }}$ days & \\
\hline LTR & $1.378^{a} \pm 0.01$ & $1.255^{\mathrm{b}} \pm 0.01$ & $1.232^{\mathrm{b}} \pm 0.008$ & $* *$ \\
\hline Phagocytic \% & $83.00^{\mathrm{a}} \pm 0.63$ & $75.80^{\mathrm{b}} \pm 0.72$ & $73.60^{\mathrm{b}} \pm 1.20$ & $* *$ \\
\hline Killing \% & $80.60^{a} \pm 0.50$ & $70.40^{\mathrm{b}} \pm 0.50$ & $68.40^{\mathrm{b}} \pm 1.07$ & $* *$ \\
\hline
\end{tabular}

Means in the same row with different superscript letters are significantly different. **Highly significant difference at $\mathrm{P} \leq 0.01$. LTR=Lymphocyte transformation rate, $\mathrm{LSD}=$ Lumpy skin disease, $\mathrm{SE}=$ Standard error

Table-2: Alteration in erythrogram in cows naturally infected with LSD virus (mean values $\pm \mathrm{SE}$ ).

\begin{tabular}{|c|c|c|c|c|}
\hline \multicolumn{5}{|c|}{ Groups } \\
\hline \multirow[t]{3}{*}{ Parameters } & \multirow{3}{*}{$\begin{array}{c}\text { Healthy } \\
\text { control } \\
\text { cows }\end{array}$} & \multicolumn{3}{|c|}{ LSD infected cows } \\
\hline & & \multicolumn{2}{|c|}{ Post-infection } & \multirow[t]{2}{*}{ F test } \\
\hline & & $1^{\text {st-2 }}{ }^{\text {nd }}$ day & $10-14^{\text {th }}$ days & \\
\hline RBCs count $\left(\times 10^{6} / \mu \mathrm{l}\right)$ & $7.42^{\mathrm{a}} \pm 0.11$ & $7.19^{\mathrm{a}} \pm 0.04$ & $6.65^{b} \pm 0.08$ & $* *$ \\
\hline $\mathrm{Hb}(\mathrm{g} \%)$ & $10.9^{\mathrm{a}} \pm 0.25$ & $10.9^{\mathrm{a}} \pm 0.07$ & $9.2^{b} \pm 0.06$ & ** \\
\hline PCV (\%) & $34.20^{\mathrm{a}} \pm 0.54$ & $34.46^{a} \pm 0.22$ & $30.44^{b} \pm 0.38$ & $* *$ \\
\hline $\operatorname{MCV}(\mathrm{fl})$ & $46.00^{b} \pm 0.00$ & $46.00^{\mathrm{b}} \pm 0.00$ & $48.00^{\mathrm{a}} \pm 0.00$ & ** \\
\hline $\mathrm{MCH}(\mathrm{pg})$ & $14.96^{\mathrm{a}} \pm 0.15$ & $15.22^{\mathrm{a}} \pm 0.16$ & $13.76^{b} \pm 0.18$ & $* *$ \\
\hline $\mathrm{MCHC}(\%)$ & $32.52^{\mathrm{a}} \pm 0.25$ & $31.68^{\mathrm{a}} \pm 0.33$ & $30.54^{b} \pm 0.27$ & $* *$ \\
\hline
\end{tabular}

Means in the same row with different superscript letters are significantly different. $* *$ Highly significant difference at $\mathrm{p} \leq 0.01$, *significant difference at $\mathrm{P} \leq 0.05$. SE $=$ Standard error, $\mathrm{PCV}=$ Packed cell volume, RBCs=Red blood cell, $\mathrm{MCV}=$ Mean corpuscular volume, $\mathrm{MCH}=$ Mean corpuscular hemoglobin, $\mathrm{MCHC}=$ Mean corpuscular hemoglobin concentration, LSD=Lumpy skin disease

Table-3: Alteration in leucogram in cows naturally infected with LSD virus (mean values \pm SE).

\begin{tabular}{|c|c|c|c|c|}
\hline \multicolumn{5}{|c|}{ Groups } \\
\hline \multirow[t]{3}{*}{ Parameters } & \multirow{3}{*}{$\begin{array}{c}\text { Healthy } \\
\text { control } \\
\text { cows }\end{array}$} & \multicolumn{3}{|c|}{ LSD infected cows } \\
\hline & & \multicolumn{2}{|c|}{ Post-infection } & \multirow[t]{2}{*}{ F test } \\
\hline & & $1^{\text {st }}-2^{\text {nd }}$ day & $10-14^{\text {th }}$ days & \\
\hline WBC count $\left(\times 10^{3} / \mu \mathrm{l}\right)$ & $9.62^{b} \pm 0.14$ & $7.10^{c} \pm 0.14$ & $15.82^{\mathrm{a}} \pm 0.99$ & $* *$ \\
\hline $\operatorname{LYM}\left(\times 10^{3} / \mu \mathrm{l}\right)$ & $5.60^{a} \pm 0.28$ & $3.04^{b} \pm 0.24$ & $7.42^{\mathrm{a}} \pm 1.17$ & $* *$ \\
\hline $\operatorname{MID}\left(\times 10^{3} / \mu \mathrm{l}\right)$ & $1.39^{b} \pm 0.03$ & $0.74^{c} \pm 0.05$ & $3.03^{a} \pm 0.12$ & $* *$ \\
\hline GRA $\left(\times 10^{3} / \mu\right)$ & $2.63^{b} \pm 0.03$ & $3.32^{b} \pm 0.03$ & $5.37^{a} \pm 0.03$ & $*$ \\
\hline
\end{tabular}

Means in the same row with different superscript letters are significantly different. $* *$ Highly significant difference at $\mathrm{p} \leq 0.01$, *significant difference at $\mathrm{p} \leq 0.05$. SE=Standard error, WBC=white blood cell, GRA=Neutrophil, eosinophil and basophil, MID=Monocytes and some eosinophil, MCV=Mean corpuscular volume, $\mathrm{MCH}=$ Mean corpuscular hemoglobin, $\mathrm{MCHC}=$ Mean corpuscular hemoglobin concentration, LSD=Lumpy skin disease 
Table-4: Alteration in some biochemical parameters in cows naturally infected with LSD virus (mean values \pm SE).

\begin{tabular}{|c|c|c|c|c|}
\hline \multicolumn{5}{|c|}{ Groups } \\
\hline \multirow[t]{3}{*}{ Parameters } & \multirow{3}{*}{$\begin{array}{l}\text { Healthy } \\
\text { control }\end{array}$} & \multicolumn{3}{|c|}{ LSD infected cows } \\
\hline & & \multicolumn{2}{|c|}{ Post-infection } & \multirow[t]{2}{*}{$F$ test } \\
\hline & & $1^{\text {st-2 }} 2^{\text {nd }}$ day & $10-14^{\text {th }}$ days & \\
\hline Total protein $(\mathrm{g} / \mathrm{dl})$ & $6.95^{\mathrm{a}} \pm 0.12$ & $6.10^{\mathrm{b}} \pm 0.10$ & $6.04^{b} \pm 0.21$ & $*$ \\
\hline Albumin $(\mathrm{g} / \mathrm{dl})$ & $3.80^{\mathrm{a}} \pm 0.12$ & $2.40^{\mathrm{b}} \pm 0.17$ & $2.32^{b} \pm 0.10$ & $* *$ \\
\hline Globulin (g/dl) & $3.15^{\mathrm{b}} \pm 0.18$ & $3.70^{\mathrm{a}} \pm 0.11$ & $3.72^{\mathrm{a}} \pm 0.12$ & $*$ \\
\hline a globulins (g/dl) & $1.11^{\mathrm{a}} \pm 0.12$ & $1.01^{\mathrm{ab}} \pm 0.12$ & $0.91^{\mathrm{b}} \pm 0.12$ & $*$ \\
\hline$\beta$ globulins ( $\mathrm{g} / \mathrm{dl}$ ) & $0.74^{a} \pm 0.12$ & $0.68^{a} \pm 0.12$ & $0.73^{a} \pm 0.12$ & NS \\
\hline Y globulins (g/dl) & $1.30^{\mathrm{b}} \pm 0.12$ & $2.01^{\mathrm{a}} \pm 0.12$ & $2.08^{a} \pm 0.12$ & $* *$ \\
\hline CK-MM (U/L) & $240.2^{\mathrm{c}} \pm 1.88$ & $297.8^{b} \pm 2.10$ & $311.4^{\mathrm{a}} \pm 2.97$ & $* *$ \\
\hline $\operatorname{ALT}(U / L)$ & $17.26^{\mathrm{b}} \pm 0.79$ & $30.54^{\mathrm{a}} \pm 0.88$ & $30.88^{\mathrm{a}} \pm 1.23$ & $* *$ \\
\hline AST $(U / L)$ & $47.22^{\mathrm{b}} \pm 1.35$ & $62.58^{\mathrm{a}} \pm 1.40$ & $63.12^{\mathrm{a}} \pm 2.41$ & $* *$ \\
\hline Creatinine (mg/dl) & $0.55^{\mathrm{b}} \pm 0.03$ & $1.50^{\mathrm{a}} \pm 0.13$ & $1.47^{\mathrm{a}} \pm 0.04$ & $* *$ \\
\hline Urea (mg/dl) & $15.4^{b} \pm 0.97$ & $21.2^{\mathrm{a}} \pm 0.58$ & $21.6^{a} \pm 0.87$ & $* *$ \\
\hline
\end{tabular}

Means in the same row with different superscript letters are significantly different. $* *$ Highly significant difference at $p \leq 0.01$. *Significant difference at $p \leq 0.05$. NS = Not significant, $A S T=A s p a r t a t e$ aminotransferase, ALT =Alanine aminotransferase, $\mathrm{CK}-\mathrm{MM}=$ Creatine phosphokinase, $\mathrm{LSD}=$ Lumpy skin disease

importance not only induce damaged hides [33], but also involvement of muscle. On the other side, there were highly significant increases in serum activities of ALT and AST in LSD infected cows when compared to healthy control. These results may be due to liver function disturbance [34]. The increase in AST may be also due to the heart muscle and the general tissue breakdown caused by the virus or secondary bacterial infection [35]. Moreover, there was a significant increase in serum creatinine level in LSD cows, this result indicate the direct effect on the kidney by LSDV [28] while a significant increase in blood urea nitrogen in diseased animals in comparison with apparently healthy groups. This could be due to protein breakdown increased in hyperthermia [32].

\section{Conclusion}

LSDV infected cows in early stages revealed leucopenia and immunosuppressive effect, so immunostimulant therapy is required. In late stage revealed hemolytic anemia, leucocytosis and increase of serum $\mathrm{CK}$ which could aid in diagnosis. Disturbance in liver and kidney function tests have been occurred.

\section{Authors' Contributions}

ANFN collected and examined samples, planned the study design, drafted and revised the manuscript and read and approved the final manuscript.

\section{Acknowledgments}

The author would like to thank Prof. Dr. AbdelMoneim A. Ali Professor and Head of Pathology Department, Faculty of Veterinary Medicine at Zagazig University for valuable help in examining and reading histopathological slides. This work was done on author's expense without funding from any organization. Necessary facilities of Department of Clinical pathology, Faculty of Veterinary Medicine, Zagazig University were used.

\section{Competing Interests}

The author declare that they have no competing interests.

\section{References}

1. Tuppurainen, E. and Oura, C. (2012) Lumpy skin disease: An emerging threat to Europe, the middle east and Asia. Transbound. Emerg. Dis., 59: 40-48.

2. Maclachlan, N. and Dubovi, E. (2011) Fenner's Veterinary Virology. Academic Press, New York.

3. Salib, F. and Osman, A. (2011) Incidence of lumpy skin disease among Egyptian cattle in Giza Governorate, Egypt. Vet. World, 4: 162-167.

4. El-Neweshy, M., El-Shemey, T. and Youssef, S. (2013) Pathologic and immunohistochemical findings of natural lumpy skin disease in Egyptian cattle. Pak. Vet. J., 33(1): 60-64.

5. Abera, Z., Degefu, H., Gari, G. and Ayana, Z. (2015) Review on epidemiology and economic importance of lumpy skin disease. Int. J. B. A. Vir., 4(1): 8-21.

6. OIE. (2010) Lumpy Skin Disease. World Organization for Animal Health, Paris, France.

7. Irons, P., Tuppurainen, E. and Venter, E. (2005) Excretion of lumpy skin disease virus in bull semen. Theriogenology, 63: 1290-1297.

8. Duguma, B., Kechero, Y. and Janssens, G. (2012) Survey of major diseases affecting dairy cattle in Jimma Town, Oromia, Ethiopia. Glob. Vet., 8(1): 62-66.

9. Chihota, C., Rennie, L., Kitching, R. and Mellor, P. (2003) Attempted mechanical transmission of lumpy skin disease virus by biting insects. Med. Vet. Entomol., 17: 294-300.

10. Hailu, B., Alemayehu, G. and Seid, N. (2015) Economic importance and control techniques of lumpy skin diseases. Anim. Vet. Sci., 3(2): 58-66.

11. El-Nahas, E., El-Habbaa, A., El-bagoury, G. and Radwan, M. (2011) Isolation and identification of lumpy skin disease virus from naturally infected buffaloes at Kaluobia, Egypt. Glob. Vet., 7(3): 234-237.

12. Ali, A., Esmat, M., Attia, H., Selim, A. and Abdel-Hamid, Y. (1990) Clinical and pathological studies on lumpy skin disease in Egypt. Vet. Rec., 127: 549-550.

13. Brenner, J., Haimovitz, M., Oron, E., Stram, Y., Fridgut, O., Bumbarov, V., Kuznetzova, L., Oved, Z., Waserman, A., Garazzi, S., Perl, S., Lahav, D., Edery, N. and Yadin, H. (2006) Lumpy Skin Disease (LSD) in a large dairy herd in Israel, June 2006. Isr. J. Vet. Med., 61: 73-77. 
14. Bounous, D.I., Campagnoli, R.P. and Brown, J. (1992) Comparison of MTT colorimetric assay and titrated thymidine uptake for lymphocyte proliferation assay using chicken splenocyte. Avian Dis., 36: 1022-1027.

15. Woldehiwet, Z. and Rowan, T.G. (1990) Some observation on the effects of age on the phagocytosis and killing of $S$. aureus by polymorphnuclear leucocytes. Br. Vet. J., 146: $165-172$.

16. Laurell, C. (1966) Quantitative estimation of proteins by electrophoresis in agarose gel containing antibodies. Anal. Biochem., 15(1): 45-52.

17. Reitman, S. and Frankel, S. (1957) A colorimetric method for determination of serum glutamicoxaloacetic transaminase and serum glutamic pyruvic transaminase. Am. J. Clin. Pathol., 25: 56.

18. Husdan, H. and Rapoport, K. (1968) Chemical determination of creatinine with deproteinization. Clin. Chem., 14: 222-238.

19. Putton, C. and Crouch, S. (1977) Determination of serum blood urea nitrogen. Anal. Chem., 49: 464-469.

20. Bancroft, J., Stevens, A. and Turner, D. (1996) Theory and Practice of Histopathological Techniques. Churchill Livingstone, New York.

21. Tamhane, A. and Dunlop, D. (2000) Statistic and Data Analysis from Elementary to Intermediate Prentice Hall. Upper Saddle River, New Jersey.USA.

22. Coetzer, J. and Tuppurainen, E. (2004) Lumpy Skin Disease. Vol. 2. Oxford University Press, South Africa. p1-12.

23. Tageldin, M., Wallace, D., Gerdes, G., Putterill, J., Greyling, R., Phosiwa, M., Al Busaidy, R. and Al Ismaaily, S. (2014) Lumpy skin disease of cattle: An emerging problem in the Sultanate of Oman. Trop. Anim. Health Prod., 46: 241-246.

24. Ahmed, A. and Dessouki, A. (2013) Abattoir-based survey and histopathological findings of lumpy skin disease in cattle at Ismailia Abattoir. Int. J. Biosci. Biochem. Bioinformatics, 3(4): 372-375.
25. Ismail, S.M. and Yousseff, F.M. (2006) Clinical, hematological, biochemical and immunological studies on lumpy skin disease in Ismailia Governorate. SCVMJ., X(1): 393-400.

26. Zhang, J. and Huang, Y. (2006) The immune system: A new look at pain. Chin. Med. J., 119: 930-938.

27. Douglas, K. and Wardrop, K.J. (2010) Schalm's Veterinary Hematology. Black Well, Philadelphia and Baltimore.

28. Coles, E. (1986) Veterinary Clinical Pathology. W. B. Saunders Company, Philadelphia and London.

29. Kumar, V., Cotran, R. and Robbins, S. (2007) Robbins Basic Pathology: With Veterinary Consult Access. Saunders, Philadelphia.

30. Hassan, H.Y., El-Kirdasy, A. and Ali, M.A. (2011) Immunobiochemical profile in cattle infected with lumpy skin disease. J. Basic Appl. Chem., 1(2): 21-25.

31. Agag, B., Mousa, S., Hassan, H., Saber, M., El-Deghidy, N. and Abdel-Aziz, A. (1992) Clinical, serological and biochemical studies on lumpy skin disease. J. Appl. Anim. Res., 1(1): 13-23.

32. Kaneko, J.J., Harvey, J.W. and Bruss, M.L. (1997) Clinical Biochemistry of Domestic Animals. Academic Press, California, USA.

33. Body, M., Singh, K., Hussain, M., Al-Rawahi, A., Al-Maawali, M., Al-Lamki, K. and Al-Habsy, S. (2012) Clinico-histopathological findings and PCR based diagnosis of lumpy skin disease in the Sultanate of Oman. Pak. Vet. J., 32: 206-210.

34. Abdalla, M.A. and Gawad, S.M. (1992) Characterization of serum lysosomal enzymatic activities II effect of lumpy skin disease in Egypt. Dtsch. Tierarztl. Wochenschr., 99(8): 347-349.

35. Agag, B.L., Hafiz, M.A., Ragab, A., Tawfik, A., Mousa, H.L., Shaker, M. and El-Danal, N. (1989) Changes in serum biochemical component of cattle suffering from LSD in Egypt. J. Comp. Pathol. Chin. Path., 2(2): 9-25. 